\title{
СТАН РОЗРОБЛЕНОСТІ ПРОБЛЕМИ ФОРМУВАННЯ МОВНОӤ КОМПЕТЕНТНОСТІ В ОФІЦЕРІВ ВІЙСЬКОВИХ ЧАСТИН НАЦІОНАЛЬНОЇ ГВАРДІЇ УКРАЇНИ
}

\author{
Лютий В. М. \\ викладач служби мовної підготовки мовного відділення \\ Національна академія Національної гвардії України \\ майдан Захисників України, 3, Харків, Украӥна \\ orcid.org/0000-0003-0235-2475 \\ liutyi37@gmail.com
}

\begin{abstract}
Ключові слова: мовна компетентність, професійна підготовка офіиерів, наукові підходи, технологіі, умови формування мовної компетентності.
\end{abstract}

\begin{abstract}
Актуальність статті зумовлена наявністю розбіжностей у тлумаченні поняття «мовна компетентність», усвідомлення означеної проблеми, а також потребою вивчення стану розробленості проблеми формування мовної компетентності офіцера НГУ для більш ефективногоїі формування. Метою статті є з'ясування зміст терміна «мовна компетентність» і їі місця в структурі професійної компетентності офіцера НГУ, узагальнення теоретичних підходів їі формування із урахуванням принципів навчання, визначення використання різноманітних технологій навчання, методів і форм навчання, впровадження педагогічних, дидактичних, організаційних умов формування мовної компетентності офіцера.

Як свідчить аналіз наукової літератури, вченими досліджено певні аспекти порушеної проблеми. А отже, нами проведено синтез отриманого в ході аналізу матеріалу для узагальнення результатів.
\end{abstract}

Наукова новизна полягає у з'ясуванні змісту терміна «мовна компетентність» і іiі місця у структурі загальної та професійної компетентності офіцера НГУ. Визначено, що поняття «іншомовна компетентність», «іншомовна професійна компетентність», «іншомовна комунікативна компетентність» $є$ дзеркальним відображенням сутності і структури базового поняття «мовна компетентність» 3 урахуванням особливостей професійної підготовки фахівця, і відрізняє їх від мовної компетентності лише додатковий фактор вивчення іноземної мови, а мовну компетентність можна формувати як на базі рідної мови, так і на базі іноземної мови. Узагальнено теоретичні підходи і технології, методики формування мовної компетентності із урахуванням принципів навчання, визначено використання різноманітних технологій навчання, методів і форм навчання, впровадження педагогічних, дидактичних, організаційних умов формування мовної компетентності офіцера. Доведено, що всі наявні дослідження стосуються переважно формування мовної компетентності майбутніх офіцерів, що ми і будемо враховувати у своєму подальшому дослідженні та спиратися на них.

Перспективою подальших досліджень $є$ діагностування стану сформованості мовної компетентності офіцерів НГУ у військових частинах, розробка інструментів іiї діагностики. 


\title{
THE STATE OF RESEARCH OF THE LANGUAGE COMPETENCE DEVELOPMENT IN OFFICERS OF MILITARY UNITS OF THE NATIONAL GUARD OF UKRAINE
}

\author{
Liutyi V. M. \\ Lecturer at the Language Training Service of the Language Department \\ National Academy of the National Guard of Ukraine \\ Zakhysnykiv Ukrainy square, 3, Kharkiv, Ukraine \\ orcid.org/0000-0003-0235-2475 \\ liutyi37@gmail.com
}

Key words: language competence; professional training of officers; scientific approaches; technologies; conditions for the formation of language competence.
The relevance of the article is due to differences in the interpretation of the concept of "language competence", awareness of this problem, as well as the need to research the state of the language competence development in NGU officers for more effective formation. The aim of the article is to clarify the meaning of the term "language competence" and its place in the structure of NGU officer professional competence, to generalize theoretical approaches to its formation taking into account the principles of teaching, to determine the use of various teaching technologies, methods and forms of teaching language competence development in the officer.

According to the analysis of the scientific literature, scientists have studied certain aspects of the problem. Therefore, we conducted a synthesis of the material obtained during the analysis to summarize the results.

The scientific novelty is to clarify the meaning of the term "language competence" and its place in the structure of NGU officer general and professional competence. It is determined that the concept of "foreign language competence", "foreign language professional competence", "foreign language communicative competence" is a mirror image of the essence and structure of the basic concept of "language competence" taking into account the peculiarities of professional training and distinguishes them from language competence, and language competence can be formed both on the basis of the native language and on the basis of a foreign language. Theoretical approaches and technologies, methods of formation of language competence taking into account principles of training are generalized, use of various technologies of training, methods and forms of training, introduction of pedagogical, didactic, organizational conditions of formation of language competence of the officer is defined. The results of the study are that it is proved that all existing studies relate mainly to the formation of language competence of future officers, which we will take into account in our further study and rely on them.

The prospect of further research is to diagnose the state of language competence development in NGU officers in military units, the development of tools for its diagnosis.
Постановка проблеми. Питання формування й розвитку мовної компетентності (МК) офіцера залишається важливою упродовж всієї його служби, проте актуалізується вона лише під час залучення офіцера до заходів міжнародного співробітництва.

Оволодіння іноземною мовою офіцерами Національної гвардії України має відповідати міжнародним уявленням щодо основних компетентностей справжнього фахівця. Одним з основних інструментів створення європейського простору вищої освіти та збільшення міжнародної конкурентоспроможності європейської системи вищої освіти у базових документах Болонського процесу було визначено сприяння професійній та 
академічній мобільності, яка в першу чергу націлена на формування відповідних мовних та комунікативних компетентностей.

Поняття мовна компетентність (МК) - відносно нове для методики навчання іноземним мовам, оскільки воно з'явилось та отримало розповсюдження лише в середині XX століття. Проблема формування та розвитку мовної (іншомовної мовленнєвої) компетентності, яка активно обговорюється науковою спільнотою, демонструє значення сукупності знань про мову і принципи побудови висловлювання у структурі мовленнєвої організації суб' єкта.

Основна проблема у дослідженні МК полягає у тому, що в силу граничності поняття вивчається психологією, лінгвістикою, психолінгвістикою, філософією мови, лінгводидактикою, та, залежно від наукової парадигми та конкретних завдань часткового дослідження, зміст поняття досить сильно варіює. Наявність розбіжностей у тлумаченні поняття «мовна компетентність», усвідомлення означеної проблеми, а також потреба вивчення стану розробленості проблеми формування МК офіцера для більш ефективного іiі формування зумовили вибір теми нашої публікації.

Аналіз останніх досліджень і публікацій. Попередній огляд літератури засвідчив неодностайний підхід учених до визначення та тлумачення МК особистості. Згідно із проведеним нами аналізом МК розглядається в педагогічних дослідженнях як:

1) володіння курсантами (слухачами), а також ïх здатність та готовність до оволодіння й оперування основними мовними засобами (фонетичними (орфографічними), лексичними, граматичними) з метою сприйняття, переробки і розуміння автентичної англомовної інформації, а також іiі продукування в усному та письмовому вигляді, застосовуючи при цьому як мовні, так і позамовні (міміка і жести, рухи) та інтонаційні засоби виразності (А. Богуш, О. Трифонова, О. Кисельова [1], О. Лагодинський [2] та ін.);

2) єдність мовних професійно-комунікативної й інформаційно-когнітивної компетенцій, що забезпечує спроможність до вирішення професійних та освітніх завдань засобами мови (О. Каменський [3]);

3) якість здобувача вищої освіти, сформованість якої характеризується наявністю мотивації та потреб до формування мовленнєвої компетентності, набутими знаннями, уміннями та навичками, передбачає творчий саморозвиток, самореалізацію та рефлексію (Т. Вигранка [4]);

4) здатність використовувати мову, як засіб комунікативної дії, різних видів мовленнєвої діяльності, у зв' язку з соціальною зорієнтованістю та культурною освіченістю (А. Заслужена [5]).
Як бачимо, здебільшого МК в українських наукових розвідках розглядається як сформованість умінь і навичок, що виявляється в чотирьох основних видах мовлення - говорінні, аудіюванні, читанні та письмі. Це передбачає наявність мовних знань - фонетичних, граматичних, лексичних і навичок оперування ними, представлених мотиваційним, операційним та рефлексивним компонентами [6; 7]. Але існує потреба в узагальненні шляхів, способів, методик ії формування тощо.

Попри те, що сучасні дослідження з методики формування МК відображають різні аспекти мовної підготовки курсантів ВВНЗ до професійної діяльності, шляхи, способи, принципи і методики формування МК офіцерів НГУ є достатньою дослідженою проблемою.

Мета статті полягає в тому, щоб з'ясувати зміст терміна «мовна компетентність» і їі місце в структурі професійної компетентності офіцера НГУ, узагальнити теоретичні підходи іï формування із врахуванням принципів навчання, визначити використання різноманітних технологій навчання, методів і форм навчання, впровадження педагогічних, дидактичних, організаційних умов формування МК офіцера.

Виклад основного матеріалу дослідження. Концепція компетентностей у проекті Тюнінг [8] розглядає компетентності як динамічне поєднання природних властивостей людини, що разом iз набутими знаннями, уміннями й навичками роблять можливим компетентне виконання певної функції або професійного завдання. За видами компетентності поділяють на загальні компетентності (generic competence, transefarbe skills) та спеціальні (фахові) компетентності (subject, specific competences).

Проект Тюнінг серед загальних компетентностей виділяє інструментальні, до яких і входить усне і письмове спілкування рідною мовою та знання другої мови, і які ми розуміємо як мовну компетентність особистості. Щодо спеціальних (фахових) компетентностей, то для освітньої галузі в проекті Tuning «Освіта» розроблено перелік узагальнених компетентностей, так звані метакомпетентності, і вже до загальних метакомпетентностей входить мовна компетентність (здатність до спілкування в усній та письмовій формі рідною та іноземною мовою) [9]. Мова як інструмент спілкування пронизує всі види людської діяльності. Отже, МК може бути як загальною, так і спеціальною (фаховою) компетентністю в залежності від обраної професії здобувачем освіти, функцій професійної діяльності.

На підставі проведених досліджень Ю. Коленко [10] виокремлює комунікативні якості як один iз значущих факторів, що відображують найбільш загальну структуру вимог професійної 
діяльності до військового спеціаліста в галузі захисту інформації. Відповідно, за результатами аналізу робіт можна сказати, що питання розгляду мовної компетентності як компоненту професійної компетентності розглядається науковцями і у військовій сфері, а МК є невід'ємною від комунікативної. Таким чином, за результатами аналізу наукових джерел ми дійшли до висновку, що МК офіцера $\epsilon$ інтегративним професійним утворенням, яке $є$ сукупністю мовних знань, мовленнєвих навичок і вмінь, досвіду їх застосування в мовному середовищі й містить професійно важливі якості офіцера, що відображають здатність діяти в різноманітних професійних ситуаціях. Відповідно до стандартів вищої освіти за спеціальностями 253 , 254 та 255 галузі знань 25 «Воєнні науки, національна безпека, безпека державного кордону» для першого (бакалаврського) рівня вищої освіти однією із загальних компетентностей військового фахівця і є компетентність К09 «Здатність спілкуватися іноземною мовою», формування якої $\epsilon$ одним із завдань освітнього процесу вищого військового навчального закладу. Це і передбачає формування МК у офіцерів і курсантів ЗСУ, НГУ, ДПСУ. Водночас до стандартів військової освіти не входить МК як фахова, що $є$, на нашу думку, не досить правильно.

Не залишилося в теорії педагогіки поза увагою висвітлення питань щодо формування іншомовної компетентності військовослужбовців у ВВНЗ. Як зазначає В. Крикун у своїй роботі, іншомовна професійна компетентність як інтегративне професійне утворення $є$ сукупністю мовних знань, іншомовних мовленнєвих навичок і вмінь, досвіду їх застосування в іншомовному середовищі й містить професійно важливі якості офіцера, що відображають здатність функціонувати в іншомовному середовищі та готовність до виконання завдань під час проведення спільних бойових дій (операцій) з підрозділами НАТО [11]. Таким чином, іншомовна компетентність за своїм змістом дублює мовну компетентність, але на основі знань, вмінь лише іноземної мови, в той час як МК стосується і рідної мови.

Н. Сорокіна вважає, що професійна іншомовна компетентність грунтується на сукупності мовної, мовленнєвої, соціокультурної компетентностей, особистісному загальнонавчальному досвіді спеціаліста, набутих ним у процесі навчання у вищій школі, мотивів, цінностей і передбачає його теоретичну та практичну готовність упродовж життя використовувати іноземну мову в соціально-трудовій діяльності й професійному пізнанні [12]. Л. Гріднєва визначає комунікативну компетенцію працівників правоохоронних органів як складне духовно-практичне утворення особистості, що охоплює засвоєні соціальні норми та вимоги щодо професійного спілкування, розвинені психологічні механізми комунікативної взаємодії з людьми, набутий практичний досвід комунікативної діяльності і вважає іiі цілісним інтегративним утворенням особистості, що $є$ окремим складовим компонентом професійної комунікативної компетентності яка складається 3 відповідної мовної, мовленнєвої та соціокультурної компетенцій, формується на основі дворівневого підходу «знання - ї практична реалізація» в контексті створеного ціннісно-смислового комунікативного середовища й дозволяє реалізувати інтеркультурну комунікативну функцію правоохоронців у процесі професійної діяльності [13]. О. Мамонова розглядає професійну мовно-комунікативну компетентність правоохоронця як інтегроване особистісне утворення - сукупність знань, умінь, навичок, особистісних якостей, які дозволяють фахівцю ефективно користуватися мовою в професійній діяльності, що спрямоване на забезпечення ефективного спілкування з громадянами України та іноземцями, службового документообігу, міжособистісної професійної комунікації, конструктивної медіації в екстремальних ситуаціях [14].

На основі проведеного огляду наукових досліджень, якщо розглядати мовну компетентність як узагальнене поняття інтегрованої якості особистості, то побачимо, що структура цієї компетентності включає три основні (специфічно предметні) блоки: власне мовні, мовленнєві і комунікативні компетенції. Як бачимо, науковці виділяють такі поняття, як іншомовна компетентність, іншомовна професійна компетентність, іншомовна комунікативна компетентність. На нашу думку, ці поняття є дзеркальним відображенням базового поняття «мовна компетентність» 3 урахуванням особливостей професійної підготовки фахівця. Так, зазначені види іншомовної компетентність відрізняе від мовної компетентності лише фактор вивчення іноземної мови, а мовну компетентність можна формувати і на базі рідної мови. І структура компетентності стосується як рідної мови, так і іноземної мови. Що дозволяє розглядати як синоніми мовну та іншомовну компетентності.

Як відомо, людина повинна володіти комплексом професійно зорієнтованих знань, умінь і навичок, необхідних для успішного виконання професійних обов'язків та самореалізації. У світлі цього зростають вимоги й до мовно-мовленнєвої підготовки спеціаліста, адже «оволодіння основами будь-якої професії розпочинається із засвоєння певної суми загальних і професійних знань, а також оволодіння основними засобами розв'язання професійних завдань, що й передбачає належний рівень сформованості професійно зумовленого мовлення. Це $є$ важливою складовою частиною фахової підготовки спеціалістів усіх напрямків. 
Як свідчать результати досліджень, мовну компетентність вважають системою вироблених i засвоєних у процесі мовленнєвої діяльності (особистого спостереження мови і мовлення, спілкування, навчання тощо) мовознавчих правил, достатніх для адекватного сприйняття і вербального відтворення буттєвих явищ суб' єктами мовлення; а сутність мовленнєвої компетентності, на думку науковця, полягає у сформованості вмінь і навичок користування МК в усній чи писемній формі, у конкретних мовленнєвих ситуаціях і 3 певною метою [15]. Такий підхід до трактування мовної компетенції є більш поширеним в українській лінгводидактиці.

Узагальнюючи результати наукових досліджень, сучасні дослідники мовної компетентності називають такі наукові підходи до іiї формування у офіцерів: андрагогічний [16; 17 та ін.]; системний [18; 13; та ін.]; компетентнісний [18; 13 та ін.]; контекстний [11; 19 та ін.]; суб'єктно-діяльнісний [16; 20 та ін.]; особистісний або особистісно орієнтовний [16; 13 та ін.]; особистісно-діяльнісний [21]; акмеологічний [22; 23 та ін.]; комунікативний або комунікативно-когнітивний $[13 ; 24$ та ін.]; аксіологічний (иіннісний) [25]; інформаційно-змістовний [25]; комунікативно-діяльнісний $[18 ; 13]$; соціокультурний або культурологічний $[18 ; 26] ;$ профільно-орієнтований [18]; гуманістичний [11]; рефлексивний [18]. Ці підходи диктують необхідність реалізації певних принципів навчання для формування МК. На думку Д. Бегеки, застосовуються відомі в літературі дидактичні, лінгвістичні, психологічні і власне методичні принципи. Серед останніх такі: методичної культури навчання комунікації; професійної спрямованості комунікативної підготовки; колективного оволодіння іншомовною комунікацією; іншомовної культурологічної освіти; інтегрованості форм підготовки; індивідуального підходу; дослідницького підходу; функціональності; формування вторинної мовної особистості; оцінювання і контролю комунікативних умінь студентів [18]. О. Єфімова [27] відносить до формування МК майбутнього офіцера такі принципи: принцип управління процесом розвитку комунікативних умінь на базі його розчленування та програмування; принцип індивідуалізації в оволодінні комунікативними вміннями, що виявляе вихідний рівень їхньої сформованості, а також індивідуальні й психологічні особливості курсантів; принцип розвитку мовленнєвої активності і самостійності курсантів. О. Мамонова виділяе такі принципи мовної підготовки майбутніх правоохоронців: принцип психолого-педагогічного забезпечення особистісного включення студента до навчальної діяльності; принцип послідовного моделювання в навчальній діяльності студентів цілісного змісту, форм та умов професійної діяльності фахівців; проблемності змісту навчання, його розгортання в навчальному процесі; принцип адекватності форм організації навчальної діяльності студентів цілям та змісту освіти; принцип провідної ролі спільної діяльності, міжособистісної взаємодії та діалогічного спілкування суб'єктів освітнього процесу (викладача та студентів, студентів між собою); принцип відкритості; принцип єдності навчання та виховання особистості фахівця) [14].

У дослідженнях 3 метою формування МК науковці радять впроваджувати систему формування МК. Так, на думку П. Лозинського, система формування МК визначається як інтегративна динамічна система соціально-статусних, рольових, діяльнісних і моральних взаємин суб' єктів комунікації і служить способом організації мовленнєвих засобів, а також мотивації мовленнєвої діяльності, в межах якої важливим компонентом у системі підготовки курсантів до комунікативної діяльності є набуття навичок поза аудиторної роботи, яка передбачає створення підгрунтя для застосування набутих знань та навичок, варіантів розв'язків, прийомів спілкування в умовах нової комунікативної ситуації; знаходження розв'язків для нової комунікативної ситуації крізь призму комбінування попередньо засвоєними ідеями, знаннями та прийомами та створення нових методів для пошуку розв'язків конкретної комунікативної ситуації [28]. Ми погоджуємся цілком 3 цією думкою.

Виділяють у науково-педагогічних дослідженнях також методики формування МК. Н. Скибун [29] у своїй роботі пропонує методику формування професійної мовленнєвої компетентності, спрямовану на посилення комунікативної підготовки шляхом систематичного залучення студентів до всіх видів мовленнєвої діяльності; збагачення словникового запасу студентів термінологічною лексикою на основі професійно зорієнтованих текстів та фахових словників; системи роботи над удосконаленням культури професійного мовлення майбутніх фахівців; риторизації процесу навчання майбутніх фахівців. В. Крикун розглядає методику формування іншомовної компетентності, основу якої складають основні положення технології змішаного навчання у ВВНЗ [11], що по суті $€$ технологією цифрового навчання. Вважаємо, що всі методики мають право на застосування, якщо враховують потреби і особливості навчання як курсантів так і офіцерів.

Розкрито в дослідженні і технології формування МК майбутніх офіцерів: особистісно-орієнтовані [30; 32 та ін.]; інформаційно-комунікативні та иифрові [13 та ін.]; інноваційні технологї [14; 31]; інтерактивні технологій [13; 16 та ін.]; 
технології «кониепиії проектів» [61]; технолоzіï автономного навчання (learner autonomy and autonomous/self-directed learning) [30]; cмapm технології [16]; технології зміманого навчання [11; 33]; технології критичного мислення [16]. Усі вони $€$ концептуальними і мають право на існування, але стосуються переважно майбутніх офіцерів. Щодо офіцерів військових частин НГУ досліджень технологій не проводилося.

Вивчалися і різні форми формування МК. На думку С. Долинського, [34] $є$ форми діалогізації (превалюють діалогічні форми взаємодії, педагогічне співробітництво); проблематизації (системне створення проблемних ситуацій, умов для самостійного визначення та постановки пізнавальних завдань студентами); персоналізації (приділення уваги особистісному спілкуванню, створення сприятливих умов для партнерства); та індивідуалізації й диференціації (врахування індивідуальних особливостей та інтересів студентів), сприяння їх особистісному розвитку). До форм організації навчання МК належать і загальнодидактичні форми (лекція, практичне заняття тощо).

Методи формування МК майбутніх офіцерів розкриті в роботах Л. Нанівської, В. Черниш, В. Зінченко та ін. Так, виходячи з наукових спостережень, Л. Нанівська [35] виділяє інтенсивні методи формування МК із застосування комунікативного методу, які розділяє на три складові частини: 1) за мовним аспектом; 2) військово-термінологічним курсом; та 3) лінгвокраїнознавчим курсом. Цей перелік методів можна доповнити переліком загальнодидактичних методів, класифікованих за різними ознаками.

Дослідники виділяють такі різноманітні умови формування МК майбутнього офіцера:

Педагогічні: Я. Булахова [36] виділяє дві групи педагогічних умов - змістовні і процесуальні. Змістовні умови характеризуються раціональним i науково обгрунтованим відбором навчальної інформації, іiі структуризацією, розробкою, впровадженням і коректуванням навчальних курсів. Процесуальні умови спрямовані на визначення логіки вивчення окремих курсів, які є складовою частиною дисципліни «Іноземна мова», вибір методів, форм, засобів вивчення іноземної мови, які стають оптимальними згідно зі змістом курсу. Л. Гріднєва [13] до педагогічних умов формування іншомовної комунікативної компетенції майбутніх працівників правоохоронних органів у ВНЗ юридичного профілю включає: 1) професійно-особистісну орієнтацію навчального процесу у вищих навчальних закладах МВС України на підготовку майбутніх правоохоронців до ефективного розв'язання завдань комунікативної взаємодії з іноземними громадянами як носіями інших мов та культур; 2) створення навчально-професійних і комунікативно-пізнавальних ситуацій, спрямованих на оволодіння курсантами та студентами вищих навчальних юридичних закладів складовими частинами іншомовної комунікативної компетенції; 3) стимулювання творчої пізнавальної діяльності курсантів і студентів щодо засвоєння форм мовленнєвої взаємодії професійно-особистісного спрямування; створення мовленнєво-комунікативного середовища.

Дидактичні. Відповідно до проведених досліджень Т. Вигранка [4] у своїй дисертаційній роботі виділяє такі дидактичні умови формування мовленнєвої компетентності: 1) актуалізація мотиваційно-ціннісної основи формування мовленнєвої компетентності студентів філологічних спеціальностей; 2) створення мовленнєво-інформаційного освітнього середовища для студентів філологічних спеціальностей; 3) здійснення рефлексійної оцінки динаміки результативності сформованості мовленнєвої компетентності студентів філологічних спеціальностей.

Зазначимо, що в деяких роботах дидактичні умови належать до педагогічних, бо дидактика $\epsilon$ складовою частиною теорії педагогіки, але $\epsilon$ різні спеціальності щодо здобуття наукових звань, паспорти спеціальностей 13.00 .09 - теорія навчання і 13.00.01 історія педагогіки, порівняльна педагогіка і теорія педагогіки розрізняють педагогічні і дидактичні умови формування певних якостей, організації процесу тощо.

Організаційні: В. Вдовін [37] формулює три основні умови організації навчання: 1) спрямованість усього процесу навчання на вироблення мовних навичок, а не лише на здобуття мовних знань; ці навички уможливлюють «реалізацію мови в комунікативних актах»; 2) комунікативний характер переважної більшості вправ, що пропонуються студентам на заняттях; 3 ) розвиток у студентів потреби в іншомовній комунікації.

У О. Потебні зазначено, що кожну особистість виділяє, виокремлює щось неповторне [38]. Саме цим неповторним $\epsilon$ мовленнєвий розвиток особистості, і чим він досконаліший, тим унікальнішою $\epsilon$ комунікативна особистість, до неї можна застосувати більший спектр технологій, методик, форм, методів тощо. Як зазначає В. Руденко, особистість повинна характеризуватись різноплановістю пізнавальних інтересів, ерудованістю, досконалим володінням мовними ресурсами, багатим словниковим запасом [39]. Це дозволяє говорити про важливість використання всього різноманіття інструментів педагогічної діяльності задля успішного формування мовної компетентності здобувачів освіти

Висновки. Наукові дослідження говорять про актуальність формування мовної компетентності в системі підготовки майбутніх офіцерів на 
основі різних теоретичних підходів, врахування принципів навчання, наповнення змісту підготовки, використання різноманітних технологій навчання, методів і форм навчання, впровадження педагогічних, дидактичних, організаційних умов формування мовної компетентності. Мовна компетентність офіцера $є$ інтегративним професійним утворенням, яке $\epsilon$ сукупністю мовних знань, мовленнєвих навичок і вмінь, досвіду їх застосування в мовному середовищі й містить професійно важливі якості офіцера, що відображають здатність діяти в різноманітних професійних ситуаціях. Іншомовна компетентність, іншомовна професійна компетентність, іншомовна комунікативна компетентність $\epsilon$ дзеркальним відображенням базового поняття «мовна компетентність» 3 урахуванням особливостей професійної підготовки фахівця і відрізняє їх від мовної компетентності лише фактор вивчення іноземної мови, а мовну компетентність можна формувати і на базі рідної мови. Узагальнено наукові підходи до формування МК в офіцерів: андрагогічний, системний, компетентнісний, контекстний, суб'єктно-діяльнісний, особистісний або особистісно орієнтов- ний, особистісно-діяльнісний, акмеологічний, комунікативний або комунікативно-когнітивний, аксіологічний (ціннісний), інформаційно-змістовний, комунікативно-діяльнісний, соціокультурний або культурологічний, профільно-орієнтований, гуманістичний, рефлексивний. Виділено педагогічні, дидактичні та організаційні умови формування мовної компетентності майбутнього офіцера. Узагальнено технології формування мовної компетентності майбутніх офіцерів: особистісно-орієнтовані, інформаційно-комунікативні та цифрові інноваційні технології, інтерактивні технологій, технології «концепції проектів», технології автономного навчання (learner autonomy and autonomous/ self-directed learning), смарт-технології, технології змішаного навчання, технології критичного мислення. Але всі ці дослідження стосуються переважно формування мовної компетентності майбутніх офіцерів, що ми і будемо враховувати в своєму подальшому дослідженні та спиратися на них. Перспективою подальших досліджень $\epsilon$ діагностування стану сформованості мовної компетентності офіцерів НГУ у військових частинах, розробка інструментів іiї діагностики.

\section{ЛIТЕРАТУРА}

1. Богуш А.М., Трифонова О.С., Кисельова О.І. та ін. Формування мовної особистості на різних вікових етапах : монографія. Одеса : ПНЦ АПН України, 2008. 272 с.

2. Лагодинський О.С. Англомовна комунікативна компетентність як компонент змісту англомовної підготовки курсантів (слухачів) вищих військових навчальних закладів. Вісник Національної академії Державної прикордонної служби України. 2013. Вип. 3. URL: http://nbuv.gov.ua/UJRN/ Vnadps_2013_3_15.

3. Каменський О.I. Методика формування англомовної компетенції студентів економічних спеціальностей засобами комп'ютерних технологій : автореф. дис. ... канд. пед. наук : 13.00.02. Одеса, 2009. $20 \mathrm{c}$.

4. Вигранка Т.В. Дидактичні умови формування мовленнєвої компетентності студентів філологічних спеціальностей в освітньому середовищі закладів вищої освіти [Текст] : автореф. дис. ... канд. пед. наук : 13.00.09 ; Тернопіл. нац. пед. ун-т ім. Володимира Гнатюка. Тернопіль, 2019. 20 с.

5. Дрозд Т.М. Розвиток комунікативної компетентності вчителів філологічних спеціальностей у системі післядипломної освіти : дис. ... канд. пед. наук : спец. : 13.00.04 - теорія і методика професійної освіти ; Вінницький державний педагогічний університет ім. М. Коцюбинського. Вінниця. 2017. 275 с.

6. Заслужена А.А. Методичні рекомендації з удосконалення підготовки майбутніх філологів 3 англійської мови та літератури у ВНЗ України. Вісник національного авіаційного університету. Серія: Педагогіка, Психологія. № 7. 2015. URL: http://jrnl.nau.edu.ua/index.php/VisnikPP/article/ viewFile/10226/13427.

7. Маслак Л.П. Педагогічні умови формування культурологічної компетентності майбутніх офіцерів радіоінженерних спеціальностей : автореф. дис. ... канд. пед. наук : 13.00.04 / Житомирський державний університет імені Івана Франка. Житомир, 2010. 20 с.

8. Мороз Н.В. Формування соціокультурної компетенції як складової професійної підготовки курсантів вищих військових навчальних закладів : дис... канд. пед. наук: 13.00.04 / Національна академія Державної прикордонної служби України ім. Богдана Хмельницького. Хмельницький, 2007. 234 с.

9. Методичні рекомендації для розроблення профілів ступеневих програм, включаючи програмні компетентності та програмні результати навчання/ пер. 3 англ. Національного експерта 3 реформування вищої освіти Програми Еразмус+, д-ра техн. наук, проф. Ю.М. Рашкевича. Київ : ТОВ «Поліграф плюс», 2016. 80 c.

10. Reference Points for the Design and Delivery of Degree Programmes in. URL: http://www.unideusto.org/ tuningeu/images/stories/Publications/Education_brochure.pdf. 
11. Коленко Ю.В. Использование информационных технологий как средства формирования профессиональной компетентности курсантов военных вузов : дисс. ... канд. пед. наук : 13.00.08. Ставрополь, 2005. С. 29-30.

12. Бегека Д.А. Підготовка майбутніх магістрів іноземної філології до формування фахової комунікативної компетентності студентів педагогічного університету [Текст] : автореф. дис. ... канд. пед. наук : 13.00.04 / Нац. пед. ун-т ім. М.П. Драгоманова. Київ, 2015. 18 с.

13. Крикун В.Д. Формування іншомовної професійної компетентності майбутніх магістрів військового управління : автореф. дис ... канд. пед. наук : 13.00.04. Київ : [б.в.], 2018. 19 с.

14. Сорокіна Н.В. Формування професійної іншомовної компетентності майбутніх філологів засобами мультимедійних технологій : автореферат дис. ... канд. пед. наук : 13.00 .04 ; наук. кер. В.Г. Редько ; М-во освіти і науки України, Нац. пед. ун-т ім. М. П. Драгоманова. Київ, 2016. 22 с.

15. Гріднєва Л.М. Формування іншомовної комунікативної компетенції майбутніх працівників правоохоронних органів : автореф. дис. ... канд. пед. наук : 13.00.04 / Луган. нац. ун-т ім. Т. Шевченка. Луганськ, 2010. 20 с.

16. Мамонова О.І. Контекстна модель професійно спрямованої мовної підготовки майбутніх правоохоронців : дисертація канд. пед. наук : 13.00.04, Держ. закл. «Луган. нац. ун-т ім. Тараса Шевченка». Старобільськ, 2015. 200 с.

17. Волкова І.В. Сутність мовних компетентностей та їх проекція на методику навчання мови. Наукові записки Національного університету «Острозька академія». Серія : Філологічна. 2017. Вип. 67. C. 73-76. URL: http://nbuv.gov.ua/UJRN/Nznuoaf_2017_67_21.

18. Ковальчук В.І. Технологія навчання дорослих на основі особистісно-орієнтованого підходу : тренінг. Київ : Шк. світ, 2009. 136 с.

19. Вихрущ В.О. Контекстний підхід до освіти дорослих: теоретичний та техноматичний аналіз. Освіта дорослих: світові тендениї̈, українські реалії та перспективи : монографія / за заг. ред. акад. Н.Г. Ничкало, акад. І.Ф. Прокопенка. Інститут освіти дорослих імені І. Зязюна НАПН України, Харківський національний педагогічний університет імені Г.С. Сковороди. Харків. 2020. С. 47-57.

20. Бойко О.В. Сутність формування лідерської компетентності майбутніх офіцерів у ВВНЗ. Військова освіта : зб. наук. пр. Національного університету оборони України. 2013. № 2. С. 32-42

21. Галецький С.М. Формування комунікативної компетентності майбутніх викладачів іноземних мов засобами інформаційно-комунікаційних технологій: автореф. дис. ... канд. пед. наук : 13.00 .04 / М-во освіти і науки України, Житомир. держ. ун-т ім. Івана Франка. Житомир. 2020. 20 с.

22. Деркач А.А. Акмеология: личностное и профессиональное развитие человека : в 5 кн. Москва : Изд-во РАГС. Кн. 1: Методолого-прикладные основы акмеологических исследований. 1999. 392 с.

23. Кузибецкий А.Н. Научные основы и техники управленческой коммуникации руководителей с персоналом образовательных учреждений : уч.-метод. пособ. (дидактический комплекс коммуникативно-ориентированного курсового обучения руководителей учреждений образования). Волгоград : Изд-во ВГИПК РО, 2004. 120 с.

24. Волобуєва О.Ф. Формування професійно-комунікативної спрямованості у слухачів мовної спеціальності військових вузів (психолого-лінгвістичний аспект) : автореф. дис. ... канд. психол. наук : 20.02.02 ; Акад. Прикордон. військ України ім. Б. Хмельницького. Хмельницький, 1999. 18 с.

25. Тармаева Е.В. Развитие коммуникативной компетентности у будущих учителей : дис. ... канд. пед. наук : 13.00.01. Улан-Удэ, 2007. $174 \mathrm{c.}$

26. Боса В.П. Формування мовленнєвої компетентності майбутніх учителів іноземних мов у процесі вивчення фахових дисциплін : монографія. Житомир : Вид-во ЖДУ ім. І. Франка, 2019. 160 с.

27. Єфімова О.М. Формування іншомовної комунікативної компетентності курсантів під час оволодіння фахом у вищих військових навчальних. Вісник НТУУ «КПI». Філологія. Педагогіка : збірник наукових праць. 2013. Вип. 1. С. 95-105.

28. Лозинський П.І. Проблеми підвищення професійної комунікативної компетентності майбутнього офіцера. Педагогіка вищої та середньої школи. 2015. Вип. 44. С. 77-84. URL: http://nbuv.gov.ua/ UJRN/PVSSh 20154416.

29. Скибун Н.Д. Формування професійної мовленнєвої компетентності майбутніх фахівців туристичного профілю : автореф. дис. ... канд. пед. наук : 13.00 .02 ; Київський університет імені Бориса Грінченка. Київ, 2016. 20 с.

30. Пономарьова О.І. Новітні технології викладання іноземної мови в технічному вузі. Проблеми гуманізму і освіти: зб. матеріалів науково-метод. конф., (Вінниця, 21-22 травня 2002 р.). В 2-х томах. Том 2. Вінниця : Універсам - Вінниця, 2002. С. 140-142.

31. Формування готовності майбутніх офіцерів Збройних сил України до професійної взаємодії у міжнародних операціях з підтримання миру і безпеки [Текст] : автореф. дис. ... канд. пед. наук : 
13.00.04 / Гребенюк Леся Володимирівна ; Держ. прикордон. служба України, Нац. акад. Держ. прикордон. служби України ім. Богдана Хмельницького. Хмельницький, 2020. 20 с. ; рис., табл.

32. Голівець С.В. Сучасні погляди на поняття іншомовної мовленнєвої компетенції. Військова освіта. 2016. № 2. C. 59-66. URL: http://nbuv.gov.ua/UJRN/vios_2016_2_10.

33. Долинський Є.В. Модель формування комунікативної компетентності майбутніх перекладачів в процесі дистанційного навчання. Вісник Національного університету оборони Украӥни. 36-к наук. праць. Київ : НУОУ. 2011. Вип. 6 (25). С. 34-40.

34. Нанівська Л.Л. Особливості комунікативної компетентності майбутніх офіцерів. Науковий вісник Ужггородського начіонального університету. Серія: Педагогіка. Соціальна робота. 2018. Вип. 2. C. 192-195. URL: http://nbuv.gov.ua/UJRN/Nvuuped_2018_2_38.

35. Булахова Я.В. Педагогічні умови навчання іноземних мов майбутніх інженерів-програмістів засобами мультимедійних програм : автореф. дис. ... канд. пед. наук : 13.00 .04 ; Луган. нац. пед. ун-т ім. Т. Шевченка. Луганськ, 2007. 20 с.

36. Вдовін В.В. Комунікативний підхід як оптимальний засіб вивчення іноземної мови у ВНЗ. Вісник Наиіонального університету «Львівська політехніка». 2007. С. 15-20.

37. Потебня О.О. Полн. собр. трудов: Мысль и язык. Т. І. Москва, 1999.

38. Руденко В.М. Формування професійно-комунікативної компетентності майбутніх філологів засобами інтерактивних технологій [Текст] : автореф. дис. ... канд. пед. наук : 13.00 .04 - теорія і методика професійної освіти / Руденко Вікторія Миколаївна ; Черкаський нац. ун-т ім. Б. Хмельницького. Черкаси, 2010. 20 c.

\section{REFERENCES}

1. Bohush,A. M., Tryfonova O. S., Kyselova O. I. and others (2008). Formuvannya movnoyi osobystosti na riznykh vikovykh etapakh [Development of language identification at different age stages] [White paper].

2. Lahodynskyi, O. S. (2013). Anhlomovna komunikatyvna kompetentnist yak komponent zmistu anhlomovnoi pidhotovky kursantiv (slukhachiv) vyshchykh viiskovykh navchalnykh zakladiv [English language competence as a component of cadets' English language training]. Visnyk Natsionalnoi akademii Derzhavnoi prykordonnoi sluzhby Ukrainy, Vol. 3. http://nbuv.gov.ua/UJRN/Vnadps_2013_3_15 [in Ukrainian].

3. Kamenskyi, O. (2009). Metodyka formuvannja anglomovnoi kompetencii studentiv ekonomichnykh spetcialnostei zasobamy kompiuternyh tehnologii [Methods of forming English-language competence of students of economic specialties by means of computer technologies [Thesis of Doctoral dissertation, South-Ukrainian State University named after Ushynskii]].

4. Vyhranka, T. (2019). Dydaktychni umovy formuvannja movlennevoi kompetentnosti studentiv filologichnyh specialnostei v osvitniomu seredovyshchi zakladiv vyshchoi osvity [Didactic conditions for the formation of speech competence of students of philological specialties in the educational environment of higher education institutions [Thesis of Doctoral dissertation, Ternopil National Pedagogic University named after Hnatiuk]].

5. Drozd, T. (2017). Rozvytok komunikatyvnoi kompetentnosti vchyteliv filologichnyh specialnostei u systemi pisliadyplomnoi osvity [Development of communicative competence of teachers of philological specialties in the system of postgraduate education [Thesis of Doctoral dissertation, Vinnytcia State Pedagogic University named after Kotciubynskyi]].

6. Zasluzhena, A. A. (2015). Metodyčni rekomendaciï z udoskonalennja pidhotovky majbutnich filolohiv $z$ anhlijskoï movy ta literatury u VNZ Ukraïny. [Methodical recommendations for improving the training of future philologists in English language and literature in Ukrainian universities]. Visnyk of National Air University. Pedagogy, Psychology, Vol. 7. http://jrnl.nau.edu.ua/index.php/VisnikPP/article/ viewFile/10226/13427 [in Ukrainian].

7. Maslak, L. P. (2010). Pedahohichni umovy formuvannya kulturolohichnoyi kompetentnosti maybutnikh ofitseriv radioinzhenernykh spetsialnostey. [Thesis of Doctoral dissertation, Zhytomyr State University named after Franko]].

8. Moroz N. V. (2007). Formuvannya sotsiokulturnoyi kompetentsiyi yak skladovoyi profesiynoyi pidhotovky kursantiv vyshchykh viyskovykh navchalnykh zakladiv [Formation of socio-cultural competence as a component of professional training of cadets of higher military educational institutions [Doctoral dissertation, National academy of State border service of Ukraine named after Khmelnytcky]].

9. Metodychni rekomendatsiyi dlya rozroblennya profiliv stupenevykh prohram, vklyuchayuchy prohramni kompetentnosti ta prohramni rezultaty navchannya. (2016). [Guidelines for the development of profiles of degree programs, including program competencies and program learning outcomes]. Transl. from English Erasmus + National Expert on Higher Education Reform, Dr. Tech. Sciences, Prof. Yu. M. Rashkevich. 
10. Reference Points for the Design and Delivery of Degree Programes in Education. http://www.unideusto. org/tuningeu/images/stories/Publications/Education_brochure.pdf [in Ukrainian].

11. Kolenko, Yu. V. (2005). Ispol'zovaniye informatsionnykh tekhnologiy kak sredstva formirovaniya professional'noy kompetentnosti kursantov voyennykh vuzov [The use of information technologies as a means of forming the professional competence of cadets of military universities [Doctoral dissertation, National academy of State border service of Ukraine named after Khmelnytcky]].

12. Beheka, D. A. (2015). Pidhotovka maybutnikh mahistriv inozemnoyi filolohiyi do formuvannya fakhovoyi komunikatyvnoyi kompetentnosti studentiv pedahohichnoho universytetu. [Preparation of future Masters in foreign philology for the formation of professional communicative competence of students of the Pedagogical University [Thesis of Doctoral dissertation, National pedagogic University named after Draghomanov]].

13. Krykun, V. D. (2018). Formuvannya inshomovnoyi profesiynoyi kompetentnosti maybutnikh mahistriv viyskovoho upravlinnya [Formation of foreign language professional competence of future masters of military management [Thesis of Doctoral dissertation, National University of Defence of Ukraine named after Cherniakhovskyi]].

14. Sorokina, N. V. (2016). Formuvannya profesiynoyi inshomovnoyi kompetentnosti maybutnikh filolohiv zasobamy multymediynykh tekhnolohiy [Formation of professional foreign language competence of future philologists by means of multimedia technologies [Thesis of Doctoral dissertation, National Pedagogic University named after Dragomanov]].

15. Hridnyeva, L. M. (2010). Formuvannya inshomovnoyi komunikatyvnoyi kompetentsiyi maybutnikh pratsivnykiv pravookhoronnykh orhaniv [Formation of foreign language communicative competence of future law enforcement officers [Thesis of Doctoral dissertation, Lughansk National University named after Shevchenko]].

16. Mamonova, O. I. (2015). Kontekstna model profesiyno spryamovanoyi movnoyi pidhotovky maybutnikh pravookhorontsiv. [Contextual model of professionally oriented language training of future law enforcement officers [Doctoral dissertation, Lughansk National University named after Shevchenko]].

17. Volkova, I. V. (2017). Sutnist movnykh kompetentnostey ta yikh proektsiya na metodyku navchannya movy. [The essence of language competencies and their projection on the methodology of language learning]. Science notes of the "Ostrog Academy" National University. Philology, 67, 73-76. http://nbuv.gov.ua/ UJRN/Nznuoaf_2017_67_21 [in Ukrainian].

18. Kovalchuk, V. I. (2009). Tekhnolohiya navchannya doroslykh na osnovi osobystisno-oriyentovanoho pidkhodu : treninh [Technology of adult learning based on personality-oriented approach: training]. Shkilnyi svit.

19. Vyhrusch, V. A. (2020). Kontekstnyy pidkhid do osvity doroslykh: teoretychnyy ta tekhnomatychnyy analiz. Osvita doroslykh: svitovi tendentsiyi, ukrayinski realiyi ta perspektyvy [Contextual approach to adult education: theoretical and technomatic analysis. Adult education: world trends, Ukrainian realities and prospects [white paper]. Kharkiv National Pedagogical University named after G.S. Skovoroda].

20. Boyko, O. V. (2013). Sutnist formuvannya liderskoyi kompetentnosti maybutnikh ofitseriv u VVNZ [The essence of the formation of leadership competence of future officers in higher education]. Military education, 2, 32-42.

21. Galetsky, S. M.(2020). Formuvannya komunikatyvnoyi kompetentnostimaybutnikh vykladachivinozemnykh mov zasobamy informatsiyno-komunikatsiynykh tekhnolohiy [Formation of communicative competence of future teachers of foreign languages by means of information and communication technologies [Thesis of Doctoral dissertation State University named after Ivan Franko].

22. Derkach, A. A. (1999) Akmeologiya: lichnostnoye i professional'noye razvitiye cheloveka [Akmeology: personal and professional development of a person]. Book 1: Methodological and applied foundations of acmeological research. RAGS Publishing House.

23. Kuzibetsky, A. N. (2004). Nauchnyye osnovy i tekhniki upravlencheskoy kommunikatsii rukovoditeley $s$ personalom obrazovatel'nykh uchrezhdeniy : uch.-metod. posob. (didakticheskiy kompleks kommunikativno-oriyentirovannogo kursovogo obucheniya rukovoditeley uchrezhdeniy obrazovaniya) [Scientific foundations and techniques of managerial communication between managers and personnel of educational institutions: teaching method. manual. (didactic complex of communication-oriented course training for heads of educational institutions)]. Publishing house of VGIPK RO.

24. Volobueva, O. F. (1999). Formuvannya profesiyno-komunikatyvnoyi spryamovanosti u slukhachiv movnoyi spetsialnosti viyskovykh vuziv (psykholoho-linhvistychnyy aspekt) [Formation of professional and communicative orientation in students of the language specialty of military universities (psychological and linguistic aspect) [case-study Academy of Border troops of Ukraine named after B. Khmelnytsky]. 
25. Tarmaeva, E. V. (2007). Razvitiye kommunikativnoy kompetentnosti u budushchikh uchiteley [Development of communicative competence in future teachers [Doctoral dissertation].

26. Bosa, V. P. (2019). Formuvannya movlennyevoyi kompetentnosti maybutnikh uchyteliv inozemnykh mov u protsesi vyvchennya fakhovykh dystsyplin [Formation of speech competence of future teachers of foreign languages in the process of studying professional disciplines. [White paper].

27. Yefimova, O. M. (2013). Formuvannya inshomovnoyi komunikatyvnoyi kompetentnosti kursantiv pid chas ovolodinnya fakhom $u$ vyshchykh viyskovykh navchalnykh zakladakh [Formation of foreign language communicative competence of cadets during mastering the profession in higher military educational establishments]. Bulletin of NTUU "KPI". Philology. Pedagogy: a collection of scientific works.

28. Lozynsky,P.I.(2015). Problemypidvyshchennya profesiynoyi komunikatyvnoyi kompetentnostimaybutnoho ofitsera [Problems of improving the professional communicative competence of the future officer]. Higher and secondary school pedagogy, Vol. 44. URL: http://nbuv.gov.ua/UJRN/PVSSh_2015_44_16 [in Ukrainian].

29. Skibun, N. D. (2016). Formuvannya profesiynoyi movlennyevoyi kompetentnosti maybutnikh fakhivtsiv turystychnoho profilyu [Formation of professional speech competence of future specialists of a tourist profile [Thesis of Doctoral dissertation Borys Hrinchenko University of Kyiv].

30. Ponomareva, O. I. (2002). Novitni tekhnolohiyi vykladannya inozemnoyi movy v tekhnichnomu vuzi [The latest technologies of teaching a foreign language in a technical university]. Problems of humanism and education, Vol. 2.

31. Grebenyuk, L. V. (2020). Formuvannya hotovnosti maybutnikh ofitseriv Zbroynykh syl Ukrayiny do profesiynoyi vzayemodiyi u mizhnarodnykh operatsiyakh z pidtrymannya myru i bezpeky [Formation of readiness of future officers of the Armed Forces of Ukraine for professional interaction in international operations to maintain peace and security [Thesis of doctoral dissertation National academy State border. service of Ukraine named after Bohdan Khmelnytsky].

32. Golivets, S. V. (2016). Suchasni pohlyady na ponyattya inshomovnoyi movlennyevoyi kompetentsiyi [Modern views on the concept of foreign language speech competence]. Viiskova osvita, 2, 59-66. http://nbuv.gov.ua/UJRN/vios_2016_2_10 [in Ukrainian].

33. Dolynsky, E. V. (2011). Model formuvannya komunikatyvnoyi kompetentnosti maybutnikh perekladachiv $v$ protsesi dystantsiynoho navchannya [Model of formation of communicative competence of future translators in the process of distance learning]. Bulletin of the National University of Defense of Ukraine, 6(25), 34-40.

34. Nanivska, L. L. (2018). Osoblyvosti komunikatyvnoyi kompetentnosti maybutnikh ofitseriv [Peculiarities of communicative competence of future officers]. Scientific Bulletin of Uzhhorod National University. Pedagogy, 2, 192-195. URL: http://nbuv.gov.ua/UJRN/Nvuuped_2018_2_38 [in Ukrainian].

35. Bulakhova, Ya. V. (2007). Pedahohichni umovy navchannya inozemnykh mov maybutnikh inzhenerivprohramistiv zasobamy multymediynykh prohram [Pedagogical conditions for teaching foreign languages to future software engineers by means of multimedia programs [Thesis of doctoral dissertation Nat. ped. Univ. named after T.H. Shevchenko].

36. Vdovin, V. V. (2007). Komunikatyvnyy pidkhid yak optymalnyy zasib vyvchennya inozemnoyi movy u VNZ [Communicative approach as the optimal means of learning a foreign language in higher education]. Bulletin of the National University "Lviv Polytechnic".

37. Potebnya, O. O. (1999). Poln. sobr. trudov: Mysl i yazyk [Full. collection of researches: Thought and language].

38. Rudenko, V. M. (2010). Formuvannya profesiyno-komunikatyvnoyi kompetentnosti maybutnikh filolohiv zasobamy interaktyvnykh tekhnolohiy [Formation of professional and communicative competence of future philologists by means of interactive technologies [Thesis of Doctoral dissertation Cherkasy national Univ. B. Khmelnytsky]. 